\title{
Implementation of Character Education during the Pandemic In Tk Aisyiyah 1 Gurah Kediri
}

\author{
Futika Permatasari \\ futika@kahuripan.ac.id \\ Fakultas Keguruan dan Ilmu Pendidikan \\ Universitas Kahuripan Kediri
}

\begin{abstract}
The purpose of this study was to determine the implementation of the Strengthening Character Educationpolicy based on Regulation of the Minister of Education and Culture (Permendikbud) Number 20 of 2018 during the Covid 19 pandemic. This study used a descriptive qualitative research method. The data sources were the principal and teachers in TK Aisyiyah 1 Gurah Kediri. Based on the research results, it is known that there are three stages in the implementation of Strengthening Character Education (PPK), namely through planning, implementation and evaluation activities. Religiosity, nationalism, independence, mutual cooperation, and integrity as character value listed in Permendikbud No. 20 of 2018are integrated into the kindergarten curriculum, namely aspects of religious and moral values, social emotional, language, cognitive, art, physical motor skills, Al Islam and Kemuhammadiyahan. During the pandemic, learning activities at TK Aisyiyah 1 Gurah were attempted to achieve the target by planning student activities at Home Learning. The learning process uses a portfolio system through groups on one of the messaging platforms. PPK integrated curriculum evaluation is carried out periodically to find out the deficiencies and necessary improvements.
\end{abstract}

Keywords: Implementation, education character, kindergarten

(C) 2021 Futika Permatasari

This work is licensed under a Creative Commons Attribution-ShareAlike

\section{INTRODUCTION}

The formation of human character as a whole is the main goal of education. Whole human means a human who has a mature personality intellectually, emotionally and spiritually. The beginning of the formation of a human being as a whole is at an early age because this period is a sensitive period and at that time humans have experienced rapid physical, motor and intellectual development. The level of human intelligence variability occurs at an early age, namely $50 \%, 30 \%$ occurs at the age of 8 years, 20\% occurs at the age of 18 years (Sudaryanti: 2012). Early Childhood Education has an important role for children as the basis for shaping the whole human personality. Based on Law No. 20 article 1 point 14 of 2003 concerning Early Childhood Education is a coaching effort aimed at children from birth to 6 years of 
age which is carried out by providing educational stimuli to assist physical and spiritual growth and development so that children have readiness to enter education Furthermore.

Children are a valuable asset in the future so they need the right stimulation. Proper stimulation will affect development children include the level of compliance, cognitive abilities, moral, dialect, social emotional, psychomotor (Marlina \& Hazizah: 2020). Therefore, parents and teachers must be careful when providing stimulation to children because at that age the stimulation will be accepted by the brain and difficult to change. The need for character education as moral guidance so that children can understand and comply with the ethics that apply in social life (Education Office: 2017)

The importance of education for children, especially character education, encourages the government to take part by making policies embodied in Permendikbud Number 20 of 2018 concerning Strengthening Character Education in Formal Education Units by applying the values of Pancasila in character education. The Strengthening of Character Education (Penguatan Pendidikan Karakter/PPK) is an educational movement that aims to strengthen the character of students through exercise, feelings, and by sports involving schools, families and communities. The implementation of this $P P K$ is through the application of Pancasila values in character education, especially covering the five main values, namely religiosity, nationalism, independence, mutual cooperation, and integrity which are integrated in the curriculum. In this case, the implementation of $P P K$ is the responsibility of each education unit to integrate $P P K$ into the curriculum.

The current Covid 19 pandemic has an impact on the educational model, namely by eliminating direct learning in all educational institutions. Based on the Circular of the Minister of Education of Indonesia Number 4 of 2020 concerning the implementation of education policies during the Covid 19 emergency period. There are several points related to the learning model being replaced by using an online system. Even so, this $P P K$ planting must continue even though direct learning is eliminated. In this condition, it is hoped that all implementers in the field of education The role of government, teachers and various parties will take part in participating in maintaining and overseeing the implementation of this change.

Online learning especially for early childhood is not easy. Many aspects are needed in online learning, namely by planning, measuring student needs, supporting systems, teacher competence, design of learning materials, suitable platforms and evaluating student learning outcomes (Solekhah: 2020).

TK Aisyiyah 1 Gurah is a school under the auspices of Muhammadiyah that has implemented a curriculum integrated character education. During the pandemic, learning activities continued in accordance with the applicable PPK integrated curriculum but with some adjustments. Therefore, researchers want to examine the challenge of implementing Strengthening Character Education/ PPK in TK Aisyiyah 1 Gurah Kediri during the Covid 19 pandemic.

\section{METHODOLOGY}

In this review, the author took a qualitative approach. According to Cresswell (1994), qualitative research approaches are those that concentrate on processes, incidents, and novelty. Researchers are present during data collection, have direct contact with the object of study, and have a limited number of subjects. Qualitative research, 
according to Sugiyono (2008), uses researchers as a main instrument or human instrument, employs triangulation in data collection, employs inductive data analysis, and focuses on context rather than generalization in research results.

The qualitative approach is more appropriate for this study because the researcher wants to explain in greater detail how character education policies were implemented during the pandemic. This research aims to uncover significance in a natural environment, specifically in TK Aisyiyah 1 Gurah Gurah Kediri.

As a human instrument, researchers prepare, observe, interview, and analyze data. Respondents in this sample included the Kindergarten Principal and other teachers who were assumed to have a detailed understanding of the issues at hand. Data were gathered with caution in order to address issues with the application of character education policies. Main and secondary data sources are the two types of data sources. Interviews with respondents provide primary data, while school records relating to the development of character education policies provide secondary data. In this report, data was analyzed using the Miles and Huberman model (Sugiyono: 2008), which consists of three activities, namely data reduction, data display and data conlusion.

\section{RESULTS AND DISCUSSION}

Tables and maps should be discussed or commented on. Character Education is implemented as part of The National Movement for the Mental Revolution (Gerakan Nasional Revolusi Mental /GNRM), which is an educational movement to reinforce Pancasila values through the application of values whose key elements are religiosity, nationalism, freedom, mutual cooperation, and honesty, as per Permendikbud Number 20 of 2018 concerning Strengthening Character Education in Formal Education Units. Each educational unit is responsible for Strengthening of Character Education (Penguatan Pendidikan Karakter/PPK).

Based on the findings of the research, TK Aisyiyah Gempolan Kediri incorporates $P P K$ values into its curriculum through a series of curriculum development activities. Religious ideals are promoted and obtain the majority of learning activities at Aisyiyah Kindergarten since it is an Islamic educational institution. PPK values are combined with Muhammadiyah values, such as Al Islam and Muhammadiyah, faith and morality, social emotions, language, cognitive, art, and physical motor skills, in addition to curriculum growth.

\section{Planinng}

In preparing the curriculum, TK Aisyiyah has a juridical basis, namely the National Standard for Early Childhood, namely Permendikbud Number 137 of 2014. The curriculum refers to Permendikbud Number 146 of 2014 which includes KI and $K D$. The learning program at Aisyiyah 1 Gurah Kindergarten is prepared based on early childhood education standards consisting of Al Islam Education, Islamic Education and Muhammadiyah Education, Religious and Moral Values, Physical Motor, Cognitive, Language, Social Emotional and Arts (Curriculum TK Aisyiyah 1 Gurah: 2020 ). The curriculum is compiled and developed by a drafting team consisting of school principals, teachers, and school committees with assistance by resource persons and the Curriculum Development Team under the coordination of the Kediri District Education Office. The curriculum is developed according to the conditions of the educational institution. Asyiyah is an institution that is under the 
auspices of Muhammadiyah, so for the development of the curriculum it is combined with Muhammadiyah values, namely Al Islam and the introduction of the Muhammadiyah organization. Meanwhile, the juridical basis in teaching religious values is the Tarjih Muhammadiyah Decision Association.

Aisyiyah Kindergarten's learning activities begin with semester program planning activities based on the theme. Each semester is divided into several themes, beginning with the things closest to the child's heart, such as themselves, family, the environment, and the universe. So that kids can learn something useful. From one topic, basic competencies and core competencies are added with Muhammadiyah and Al Islam, and then character values are integrated. As an example, in one theme, the discussion of body members as God's creation is integrated with religious values, specifically how to give thanks and maintain God's creation while also using the limbs for good.

Curriculum development at TK Aisyiyah 1 Gurah is based on the principles of 1) considering children's potential, development, needs, character, and interests; 2) the formation of children's spiritual and social attitudes; 3) holistic integrative; 4) responsive to the development of science, technology, and art; and 5) relevance to the needs of children. 7) Put into practice by learning through play; 8) Considering the socio-cultural context of TK Aisyiyah 1 Gurah when planning learning activities via a series of curriculum document preparations (Suyatmini: 2017).

Curriculum planning is planning learning opportunities to guide students towards behavior change and then evaluating the extent to which these changes occur (Rusman: 2011). Semester Program, Weekly Learning Implementation Plan, and Daily Learning Implementation Plan (Rencana Pelaksanaan Pembelajaran Mingguan, dan Rencana Pelaksanaan Pembelajaran Harian/RPPH). The Semester Program contains a list of themes for one semester including the allocation of time for each theme by adjusting the effective day of the education calendar by dividing all basic competencies into the appropriate themes so that no competency is overlooked. The Weekly Program Implementation Plan is prepared for one week of learning which consists of Basic Competencies and activity materials that will be developed into plans for learning activities. Then, the $R P P H$, which is a daily program plan that will be carried out by educators / caregivers on a daily basis or in accordance with institutional programs during the COVID-19 pandemic, is eliminated. During the Covid 19 pandemic, Aisyiyah 1 Gurah Kindergarten students carried out Learning From Home activities. However, Kindergartens continue to strive so that the implementation of learning reaches the target according to the curriculum by planning special activities during the pandemic.

\section{Implementing}

The habituation program is the method used by TK Aisyiyah in the implementation of $P P K$. This was accomplished by incorporating the five $P P K$ values into eight development programs for TK Aisyiyah. It can cover several aspects in one activity, such as language values, social emotions, and art in cognitive activities. Furthermore, the student's ability to absorb the material being taught will be used to determine success. The following is a list of programs and learning materials available at TK Aisyiyah 1 gurah. 
Table 1. Program and Learning Content in TK Aisyiyah 1 Gurah

\begin{tabular}{|l|l|c|c|}
\hline \multirow{2}{*}{ No } & \multirow{2}{*}{ Component } & \multicolumn{2}{|c|}{ Tme Allotment of Currculum } \\
\cline { 3 - 4 } & & \multicolumn{2}{|c|}{ Level } \\
\cline { 3 - 4 } & & A & B \\
\cline { 3 - 4 } & & 1 & Thematic \\
\hline 1. & Al Islam & 1 & 1 \\
\hline 2. & Kemuhammadiyahan & 4 & 4 \\
\hline 3. & Nilai Agama dan Moral & 6 & 6 \\
\hline 4. & Motorik & 6 & 6 \\
\hline 5. & Kognitif & 6 & 6 \\
\hline 6. & Bahasa & 6 & 5 \\
\hline 7. & Sosial Emosional & 5 & 35 Hours \\
\hline 8. & Seni & 35 Hours & \\
\hline & Weekly Time Allotment & & 6 \\
\hline
\end{tabular}

Aisyiyah Kindergarten's learning content includes materials that are introduced to children in accordance with the development program. The early childhood program's learning content emphasizes the formation of attitudes, ethics, and the introduction of water love. The following are the development programs that have been implemented in TK Aisyiyah 1 Gurah.

\section{a. Particullar Programe ( Religius Value)}

The development of $A l$ Islam and Kemuhammadiyahan is one of the superior programs at TK Aisyiyah I Gurah, which is unique in achieving basic competences of ke-aisyiyahan and kemuhammadiyahan in accordance with the aim of deepening Islam and introducing religious and Muhammadiyah organizations, which are carried out with Circle Time (Repetition / Habitual) activities, memorizing prayers, practicing Dhuha Prayers, and introducing Muhammadiyah and Aisyiyah organizations, both business charities and their participation in society.

\section{b. General Program}

TK Aisyiyah has several general development programs that aim to generally develop students' abilities including the development of religious and moral values, cognitive, language, introducing moral values and good behavior through routine activities to create good behavior habits. Damapak this activity is very good for the development of the character of students in the hope that they are accustomed to and embedded in the child's mindset (Hasnah in Sri Wulandari: 2017). Development activities at TK Aisyiyah include; 1) Motor development includes planned stimulation to develop gross, smooth muscle strength. And healthy behavior; 2) Cognitive development as a facilitation program so that children know the world by means of exploration and active play so that children have experiences that support the maturity of critical, analytical, and problem solving thinking; 3) Language development is a program to improve the ability to understand the language that is conveyed (receptive), able to convey clearly and coherently (expressively), and the introduction of early literacy through the interaction of children with children, and children with parents, 4) Socio-emotional development includes embodiment of an 
atmosphere for the development of social attitudes and skills in the context of play, 5) Art development includes creating an atmosphere for the development of art appreciation in the context of play.

\section{c. Local Wisdom Programe.}

The local content development program at Aisyiyah Kindergarten is implemented through activities that increase students' abilities and skills in using regional and foreign languages. This program aims to foster responsibility in preserving cultural products (Nasir: 2013). The material presented in this program is in the form of adding vocabulary, singing songs, Javanese poetry, Arabic and English.

During the pandemic, the preparation of learning activities still paid attention to the school curriculum guidelines but with adjustments to the conditions of students carrying out Learning From Home activities. The amount of time allocated is reduced by still paying attention to the portion of each component. In planning the schedule for Learning from Home activities, students pay attention to circle time (habituation / repetition) by repeating several activities as a form of habituation and strengthening character education at home, for example, the habituation of prayers that are scheduled repeatedly as a student's task to get used to praying. There needs to be cooperation from teachers and parents as mentors at home to pay attention to the discipline and sustainability of this BDR activity.

The following is the Learning Schedule from the Aisyiyah 1 Gurah Kindergarten, which is integrated with Strengthening Character Education (Penguatan Pendidikan Karakter /PPK).

\begin{tabular}{|c|c|c|c|}
\hline Day/Date & Programe & Task Activity: Week 7 & Report \\
\hline Monday & Al Islam & Mention the procedures of $W u d h u$ & Video \\
\hline \multirow[t]{2}{*}{ 15-02-2021 } & NAM 2.14.2 & Be Friendly & Picture \\
\hline & Cognitive & Ordering Geometri in right order & Picture \\
\hline Tuesday & K.M.D 1.2 .8 & Sing a simple Muhammadiyah song & video \\
\hline \multirow[t]{2}{*}{$16-02-2021$} & Pembiasaan SE & It's good to get something & Picture \\
\hline & BHS & $\begin{array}{l}\text { Repeat the phrase "thank you my } \\
\text { teacher" }\end{array}$ & video \\
\hline \multirow{3}{*}{$\begin{array}{l}\text { Wednesday } \\
\text { 17-02-2021 }\end{array}$} & Al-Islam & $\begin{array}{l}\text { Recite the sentence thoyyibah } \\
\text { basmallah, hamdallah, istighfar }\end{array}$ & video \\
\hline & Habituall Activity & Respecting parents & Picture \\
\hline & Motion and art & $\begin{array}{l}\text { Recognizing dangerous foods to eat } \\
\text { / recognizing drugs that can be } \\
\text { taken by children }\end{array}$ & Picture \\
\hline
\end{tabular}

Thursday KMD Recite the poem written by $\mathrm{KH}$ video




\begin{tabular}{|c|c|c|c|}
\hline \multirow[t]{3}{*}{$18-02-2021$} & \multicolumn{3}{|c|}{ Ahmad Dahlan } \\
\hline & Local Wisdom & Saying 1-15 in Javanese Language & video \\
\hline & Cognitive & Role play with the little doctor & Picture \\
\hline \multirow{3}{*}{$\begin{array}{l}\text { Friday } \\
\text { 19-02-2021 }\end{array}$} & Al Islam & $\begin{array}{l}\text { Shows the symbol of the } \\
\text { Muhammadiyah Youth }\end{array}$ & Picture \\
\hline & Local Wisdom & Qoyyatun $=$ tailor & video \\
\hline & $F M$ & $\begin{array}{l}\text { Walk backwards, walk to the side } 1 \text { - } \\
2 \text { meters }\end{array}$ & video \\
\hline \multirow[t]{3}{*}{$\begin{array}{l}\text { Saturday } \\
20-02-2021\end{array}$} & Language & $\begin{array}{l}\text { Have conversations with peers / } \\
\text { adults }\end{array}$ & video \\
\hline & Local Wisdom & Dokter $=$ doctor Guru=teacher & video \\
\hline & $F M$ & Jump with balance & foto \\
\hline
\end{tabular}

Based on the data in the table above, it is possible to infer that kindergarten aims to organize learning events by creating weekly schedules to make it easier for parents to maintain the consistency of student learning activities. Every day, the development components are organized in accordance with the program, with the development components to be accomplished varying from day to day. Habituation tasks such as being respectful to others, honoring parents, and worshiping are arranged on a regular basis to help students become accustomed to these practices.

Based on the results of interviews with the Principal, in reality the implementation of activities still could not reach the target as in the activities before the pandemic. This is because the learning material is reduced by the elimination of face-to-face classes which has an impact on the lack of interaction with students. In addition, habituation is not working optimally because the habits that teachers do every day at school are replaced by habituation tasks guided by parents.

During the pandemic, learning tasks are carried out using the WhatsApp group application and the portfolio process, in which parents send their learning outcomes from home to the WhatsApp group for review by the teacher every day. For tasks that need further detail, the instructor may provide guidance. Furthermore, there are learning activities via video calls for online learning activities with 8 students in the hope that learning activities can run smoothly by keeping learning via video calls.

\section{Evaluasi}

An evaluation is carried out to obtain and discover the outcomes of learning tasks. The evaluation at TK ABA 1 Gurah encompasses the entire scope of growth relevant to Basic Competence (KD). The evaluation results are recorded in documents that include regular assessment documents, monthly evaluations, children's portfolio documents, and other documents that provide information on the results of measuring learning growth, learning outcomes, and improving the results of children's learning activities. 
The regular appraisal checklist, anecdotes, and job outcomes are all forms of evaluations at TK ABA 1 Gurah.

It is collected and recorded in the form of a portfolio based on the evaluation using the various tools and methods listed above. Based on these results, the teacher performs an analysis to draw conclusions about the overall picture of child development based on all of the measures that have been developed each semester. Self-development practices are evaluated qualitatively and communicated to schools and parents of students on a regular basis, either through written reports or through scheduled meeting forums, at TK Aisyiyah 1 Gurah. Development and monitoring tasks are paired with regular learning activities during a pandemic.

During the assessment stage, the teacher observes each child to determine their ability to learn the values learned by the teacher. Teachers could make clear observations of students prior to the pandemic, making it easier for them to offer evaluations. During the pandemic, assessment was achieved by portfolios that were collected every day, as well as the outcomes of interviews with student guardians about habituation of learning activities at home.

Curriculum evaluation is carried out twice a month to discuss student learning activities, namely discussing activities carried out and at the end of the year by inviting student guardians, teachers and foundations. Meanwhile, the committee meeting was held in April.

The obstacle to the implementation of Strengthening Character Education during the pandemic is the lack of intensity of teacher-student meetings so that it does not meet the PPK target achievement which is usually known through habituation in schools. In addition, there is a lack of intensity of meetings with parents, so that communication becomes less intensive and not all parents can work together to develop children's character.

\section{CONCLUSION}

Based on the results of the above research, the implementation of the Integrated Strengthening Character Education (Penguatan Pendidikan Karakter /PPK) curriculum during the Covid 19 pandemic at TK Aisyiyah 1 Gurah is divided into three stages, namely planning, implementation and evaluation. Planning is carried out through learning planning, namely the Semester Program, the Weekly Learning Implementation Plan, and the Daily Learning Implementation Plan (RPPH). Religious values, the characters listed in Permendikbud No. 20 of 2018, namely religiosity, nationalism, independence, mutual cooperation, and integrity are integrated into the kindergarten curriculum, namely aspects of religious and moral values, social emotional, language, cognitive, art, physical motor skills. , Al Islam and Kemuhammadiyahan. In the Learning from Home activity the school prepares a special schedule that is distributed to students every two weeks. The results of portfolio-based student activities collected via messaging platforms. The teacher provides instructions and evaluations based on the results of student portfolios and the results of discussions with parents about children's development at home.

\section{ACKNOWLEDGEMENT}

I would like to thank all those who have supported and assisted our research, so that in the end this research can be published. To all parties who have helped this 
research are all leaders and the board of teachers as well as stakeholders in TK Aisyiyah Gurah, I thank you profusely and be grateful for the completion of our research. Do not forget to also thank the Journal of Childhood Development IAIMNU Metro Lampung for publishing our research in the form of scientific articles.

\section{REFERENCES}

Cresswell. 1994. Research Design: Qualitative and Quantitative Approaches. Thousand Oaks: Sage

Dinas Pendidikan. 2017. Mengapa Perlu Adanya Pendidikan Karakter. Diakses pada 20 2020,

dari

http:// dinaspendidikan.blorakab.go.id/home/mengapa-perlu-adanyapendidikan-karakter/

Nasir, Muhammad. 2013. Pengembangan Kurikulum Muatan Lokal dalam Konteks Pendidikan Islam di Madrasah. Jurnal Hunafa https://www.jurnalhunafa.org/index.php/hunafa/article/view/12

Permendikbud Nomor 20 Tahun 2018 tentang Penguatan Pendidikan Karakter

Putranti. 2019. Penerapan Program Peguatan Pendidikan Karakter Berbasis Kelas di Sekolah Dasar Se-Kecamatan Sleman Kabupaten Sleman. Skripsi.

Rusdiyani, Efi. 2016. Pembentukan Karakter dan Moralitas Bagi Generasi Muda yang Berpedoman Pada Nilai-Nilai Pancasila Serta Kearifan Lokal. Seminar Nasional Pembentukan Karakter dan Moralitas bagi Generasi Muda yang Berpedoman pada Nilai-Nilai serta Kearifan Lokal. https:/ / publikasiilmiah.ums.ac.id/bitstream/handle/11617/10740/4\%20Efi $\%$ 20Rusdiyani.pdf?sequence $=1$ \&isAllowed $=y$

Santika, I Wayan Eka. 2020. Pendidikan Karakter Pada Pembelajaran Daring. IVCEJ $\begin{array}{lllll}\text { Volume } & 3 & \text { Nomor } & 1 & \text { Tahun }\end{array}$ 2020.https:/ / ejournal.undiksha.ac.id/index.php/IVCEJ/article/view/27830

Solekhah, H. 2020.Distance Learning of Indonesan Early Chilhood Eduction (PAUD) during the Covid 19 Pandemic. International Journal of Emerging Issues in Early Childhood Education. Volume 2 Number 22020

Sri Wulandari, Anisa. 2017. Program Pembiasaan Siswa Sekolah Dasar Muhammadiyah XI Mangkuyudan Surakarta dalam Membangun karakter Religius.

http:/ / eprints.ums.ac.id/52551/11/NASKAH\%20PUBLIKASI\%20.pdf

Sudaryanti . 2012. Pentingnya Pendidikan Karakter Bagi Anak Usia Dini. Jurnal $\begin{array}{lllll}\text { Pendidikan } & \text { Anak } & \text { Volume } & 1 & \text { Nomor }\end{array}$ https://journal.uny.ac.id/index.php/jpa/article/view/2902/2416

Sugiyono. 2008. Metode Penelitian Kuantitatif Kualitatif dan R\&D. Bandung: ALFABETA

Surat Edaran Menteri Pendidikan Indonesia Nomor 4 Tahun 2020 tentang Implementasi Kebijakan Pendidikan Pada Masa Darurat Covid 19

Suyatmini. 2017. Implementasi Kurikulum 2013 Pada Pelaksanaan Pembelajaran Akuntansi di Sekolah Menengah Kejuruan. Jurnal Pendidikan Ilmu Sosial $\begin{array}{llllll}\text { Volume } & 27 & \text { No. } & 1 & \text { Juni } & 2017 .\end{array}$ http:/ / journals.ums.ac.id/index.php/jpis/article/view/5120

Undang-undang No. 20 pasal 1 butir 14 tahun 2003 tentang Pendidikan Anak Usia Dini (PAUD) 